Original Article

\title{
ASSESSMENT OF ANALGESIC ACTIVITY OF NELUMBO NUCIFERA FRUIT ETHANOL EXTRACT
}

\author{
MUHAMMAD ALI RAJPUT ${ }^{*}$, TABASSUM ZEHRA², FIZZAH ALI², GUNESH KUMAR ${ }^{3}$
}

${ }^{1}$ Department of Pharmacology, Multan Medical and Dental College, Multan 66000, Pakistan, ${ }^{2}$ Department of Pharmacology, Liaquat National Medical College, Karachi, Pakistan, ${ }^{3}$ Lecturer department of Pharmacology, Liaquat University of Medical and Health Sciences, Jamshoro, Sindh, Pakistan

Email: drmuhammadali2016@gmail.com

Received: 23 Aug 2019, Revised and Accepted: 30 Sep 2019

\section{ABSTRACT}

Objective: Utilization of herbal remedies rich in flavonoids and vitamins have increased significantly these days to treat various disorders, thus existing research work encircled to appraise the analgesic effect of Nelumbo nucifera fruit (NNF) for evaluating its traditional use pharmacologically in disorders which are associated with pain and inflammation.

Methods: Central analgesic activity in mice was assessed by tail flick test and the latency time i.e. the removal of tail from the stimulus was recorded. Similarly acetic acid induced writhing test was also conducted for the assessment of peripheral analgesic effect in mice and number of writhes was counted along with percent inhibition of writhes.

Results: In tail flick test the peek anti-nociceptive effect at all doses of fruit was observed at $90 \mathrm{~min}$. However, the percentage of tail elongation time was highest at a dose of $200 \mathrm{mg} / \mathrm{kg}$ i.e. $82 \%$ at $90 \mathrm{~min}$. Number of writhes was highly significantly reduced at all doses of NNF but maximum effects were observed at dose $200 \mathrm{mg} / \mathrm{kg}$ as compared to control, indicating $48.41 \%$ inhibition of writhes.

Conclusion: NNF have exhibited strong analgesic effect in both animal models, which may be connected with the synergistic actions of flavonoids, saponins and tannins on arachidonic acid pathway inhibition. Hence NNF seems to have a great potential in disorders associated with pain but more experimental trials in this field are required to confirm these findings.

Keywords: Nelumbo nucifera, Tail flick test, Analgesic, Arachidonic acid

(C) 2019 The Authors. Published by Innovare Academic Sciences Pvt Ltd. This is an open access article under the CC BY license (http://creativecommons.org/licenses/by/4.0/) DOI: http://dx.doi.org/10.22159/ijpps.2019v11i11.35455

\section{INTRODUCTION}

Lots of individuals who experience severe, inexorable and excruciating pain, for instance, that resulting from cancer or injury has to rely on morphine, in spite of its established adverse outcomes. Similarly unceasing anti-inflammatory conditions such as rheumatoid arthritis and osteoarthritis are mostly treated with nonsteroidal anti-inflammatory drugs (NSAIDS). Although these synthetic agents are dominating the market but issue of toxicity with prolonged use of these agents cannot be ruled out, the most frequent being GIT bleeding and ulcers $[1,2]$. Hence there is a need to develop new, safe, effective, economical and innocuous analgesics [3].

The uses of herbal drugs are becoming progressively more popular as they are supposed to be natural, advantageous and lack unwanted effects [4]. Mostly the plant-derived drugs are taken randomly by local population for the treatment of various diseases without having adequate information regarding its usefulness. Hence for proper guidance of the general population, especially users of natural products, there is a need to scientifically prove the effectiveness of these medicinal plants [5]

Nelumbo nucifera, a Nymphaeaceae family plant is commonly cultivated in the hot and humid climatic zones of Thailand, Pakistan, India and China [6]. Its fruit contains seeds plus pods (lotus bulbs). The greencolored pods offer an add-on to the seeds, which are black, firm and round egg-shaped. They are organized in spirals and edible portion of seeds have to be peeled separately before they are eaten $[7,8]$.

Its seeds are a wonderful source of protein, starch, fat, unsaturated fatty acids and asparagines. The key active principles in seeds are flavonoids, alkaloids, principally lines nine, lotusine, isoliensinine, dauricine, pronuciferine, nuciferine, roemerine, procyanidin, neferine plus armepavine. The seeds also have carbohydrates, Gallic acid and isoquininolinol and contain ample amount of various minerals as well such as potassium, magnesium, calcium, sodium, iron, chromium, manganese, copper and zinc $[6,9,10]$.
Recently conducted study on NNF pods has shown the existence of numerous active bioactive principles in them for instance flavonoids, alkaloids, saponins, terpenoids and tannins [11]. Procyanidin (alkaloid) was also squeezed from NNF pods [6].

The fruits are commonly used up as a healthy component of Asian cuisine and also as a traditional cure of various ailments e. g. hypertension, palpitation, arrhythmia, fever, pain, inflammation, sleep disorders, chronic diarrhea, spermatorrhea, leucorrhoea, bad breath, leprosy and menorrhagia $[12,13]$. Current research work revealed $L_{50}$ value of $N N F$ higher than $5 \mathrm{~g} / \mathrm{kg}$ whereas its Neuropharmacological role was also established as an anxiolytic, antidepressant and antiepileptic agent [11, 14]; however very inadequate literature is obtainable concerning its effects as analgesic agent, therefore existing study was centered towards the evaluation of analgesic effect of NNF in order to justify its traditional use pharmacologically in disorders which are connected with pain.

\section{MATERIALS AND METHODS}

\section{Research design}

Research work was executed utilizing the laboratory facilities of Pharmacology department and the Research Institute of Pharmaceutical Sciences, University of Karachi, following approval of synopsis and after getting permission for the use of laboratory animals from the Board of Advance Studies and Research (BASR/02149/Pharm, dated 30 $0^{\text {th }}$ December 2014). Albino mice (49) of either sex weighing 20-25 g were used for tail-flick test and were divided into seven groups. Likewise albino mice (49) of either sex weighing 20-25 g were used for acetic acid-induced writhing test and were equally divided into seven groups.

\section{Animal care}

Animals were housed in polycarbonate cages with cage enrichment and were allowed to acclimatize for three weeks before the start of the experiment. The temperature was kept at about $25{ }^{\circ} \mathrm{C}$ with a relative 
humidity of 50 to $60 \%$ in alternating twelve-hour light and dark cycle. Each mouse was provided access to normal diet and water. The animals were carried to the laboratory about an hour prior to the initiation of experiments [14]. Animals were used in line with protocol from NACLAR (National Advisory Committee for Laboratory Animal Research) and NIH (National Institute of Health) $[15,16]$.

\section{Preparation of extract/Chemicals}

After obtaining fruits from the native fruit bazaar of Hyderabad, Pakistan in August 2015, they were initially presented to Pharmacognosy department, Karachi University for identification and authentication and afterward receipt no NNF-03 was deposited in the same department.

Crude extract was prepared through a cold extraction procedure $[17,18]$. Six kg fruits were initially rinsed with tap water and the seeds were separated from the pods manually The seeds have high contents of water that's why they need to be chopped first then left for $06 \mathrm{~d}$ for drying out in shade. The dried material obtained was thick so again needs to be ground into fine powder. In contrast pods were chopped once only and were allowed to dry in shade for just $03 \mathrm{~d}$. The dried pod material takes a coarse powder form. So for better separation and collection of NNF constituents (secondary metabolites) they need to be chopped and dried separately before soaking up together in ethanol (95\%) for ten days with occasional shaking.

Afterwards it was filtered using filter paper Whatman No. 1. Subsequently it was evaporated using rotary machine under condensed pressure at $40{ }^{\circ} \mathrm{C}$ to $45^{\circ} \mathrm{C}$. The condensed material was freeze dried in a freeze dryer at- $30{ }^{\circ} \mathrm{C}$. The material so gained was preserved at- $20^{\circ} \mathrm{C}$ until further use in doses of 50, 100 and 200 $\mathrm{mg} / \mathrm{kg}$ orally. The ultimate amount of the extract acquired was $400 \mathrm{~g}$ of dry weight.

Tragacanth gum was acquired from Merck whereas aspirin was obtained from one of the well-known pharmacy shops at Karachi.

$2 \%$ tragacanth gum in powder form was acquired from Merck which was consumed to make suspensions of 3 different doses of test drug i.e. NNF 50, 100 and $200 \mathrm{mg} / \mathrm{kg}$. It was given to the control group as placebo in the dose of $10 \mathrm{ml} / \mathrm{kg}$ orally. $100 \mathrm{ml}$ of warm distilled water was added in $2 \mathrm{~g}$ tragacanth gum to make $2 \%$ suspension. At each occasion new suspensions were prepared for dosing $[19,20]$.

Aspirin $300 \mathrm{mg}$ tablets were trampled and suspended in gum tragacanth (2\%) which was then administered per oral through orogastric tube in a dose of 50,100 and $200 \mathrm{mg} / \mathrm{kg}$ in tail flick test and acetic acid-induced writhing test [21].

$0.7 \%$ acetic acid in the dose of $10 \mathrm{ml} / \mathrm{kg}$ was administered IP [22].

\section{Experiments}

\section{Tail flick test}

Analgesia is the loss of ability to feel or react to painful stimulus such as chemical, thermal or mechanical [21]. In the current study central analgesic activity in mice was assessed by tail-flick test and tail-flick latency difference (TFLD) i.e. the time in seconds taken by mouse to remove its tail clearly out of water was noted as the reaction time [23].

The test was conducted on 49 white albino mice of either sex which were equally placed in seven groups $(n=7)$. Group control was administered gum tragacanth as a vehicle; three groups served as test groups and were given NNF at a dose of 50, 100 and $200 \mathrm{mg} / \mathrm{kg}$ and three groups served as reference groups and were given aspirin 50, 100 and $200 \mathrm{mg} / \mathrm{kg}$. All drugs were administered PO. NNF extract was initially tested in a dose of $20 \mathrm{mg} / \mathrm{kg}$ for $15 \mathrm{~d}$ but no significant effects were observed.

Each mouse was kept in a particular restrainer with only the tail extending out. Afterwards $1 / 3^{\text {rd }}$ of its tail was submerged in a digital constant temperature water tank maintained at $51{ }^{\circ} \mathrm{C}$. The $1^{\text {st }}$ reading was taken straightaway prior to the administration of drugs and then after 30,60, 90, 120, 150 and $180 \mathrm{~min}$. Animals which did not remove their tail in 10 seconds were discarded from the experiment in order to avoid tissue damage [24]. Data acquired was calculated utilizing the average values of every group and average increase in latency following dosing was measured. Lastly \% time elongation of tail with respect to the control group was evaluated using the following formula as previously described [25].

Average tail-flick time for sample

$\%$ Time elongation of tail $=\frac{\text { Average tail flick time for Control }}{\text { Average tail flick time for sample }} \times$

\section{Acetic acid-induced writhing test}

Acetic acid-induced writhing test is a valuable test conducted for the assessment of peripheral analgesic effects in mice by the already described method [26]. A population of 49 white albino mice of both sexes was equally placed in seven groups $(n=7)$. Control animals were given gum tragacanth as vehicle, whereas three groups served as test groups and were given NNF extract at a dose of 50, 100 and $200 \mathrm{mg} / \mathrm{kg}$. Another three groups served as reference groups and were given aspirin in a dose of 50,100 and $200 \mathrm{mg} / \mathrm{kg}$. All drugs were given orally. NNF extract was initially tested in a dose of 20 $\mathrm{mg} / \mathrm{kg}$ for $15 \mathrm{~d}$ but no significant effects were observed.

$30 \mathrm{~min}$ after the administration of drugs, $0.7 \%$ acetic acid $10 \mathrm{ml} / \mathrm{kg}$ was given IP. Mice were placed immediately in a plastic transparent box (13 cm height $\times 12 \mathrm{~cm}$ width $\times 23 \mathrm{~cm}$ length) and number of writhes which includes abdominal muscle contraction, periodic arching of body, stretching and drawing up of hind limbs were counted for twenty minutes and lastly percent inhibition of writhes was assessed using the following formula [21].

$$
\% \text { Inhibition }=\frac{\mathrm{Vc}-\mathrm{Vt}}{\mathrm{Vc}} \times 100
$$

Where:

\section{$V c=$ Average Number of writhes for control animals}

$V t=$ Average Number of writhes for treated animals

\section{Statistical analysis}

The tables obtained through experiments were used to take an average and standard error to the average utilizing two sample student T-test and values of $\mathrm{P}$ less than 0.05 were reflected as significant and P less than 0.005 as extremely significant. All numerical methods were accomplished with SPSS software version 20 [27].

\section{RESULTS}

\section{Tail flick test}

Table-1 has depicted the analgesic activity of NNF and aspirin using the tail-flick test. The table has summarized the results of NNF at doses 50, 100 and $200 \mathrm{mg} / \mathrm{kg}$ against control and also with similar doses of aspirin. It was revealed that NNF at dose $50 \mathrm{mg} / \mathrm{kg}$ exhibited extremely noteworthy analgesic effects at 30,60 and 90 min and noteworthy effects at 120 and $150 \mathrm{~min}$ in comparison to control. Whereas NNF at doses 100 and $200 \mathrm{mg} / \mathrm{kg}$ exhibited highly noteworthy analgesic effects from 30 to $180 \mathrm{~min}$ as compared to control. Aspirin, in contrast, revealed extremely noteworthy analgesic effects at 50,100 and $200 \mathrm{mg} / \mathrm{kg}$ from 30 to $180 \mathrm{~min}$ as compared to control. Table 2 has demonstrated \% tail elongation time at 90 min after administration of NNF and aspirin with respect to control. NNF showed highest \% tail elongation time at $200 \mathrm{mg} / \mathrm{kg}$ dose i.e. $82 \%$ followed by $76 \%$ and $42 \%$ for extract doses 100 and $50 \mathrm{mg} / \mathrm{kg}$. Aspirin, on the other hand, exhibited \% tail elongation time of 81,84 and $95 \%$ at doses 50,100 and $200 \mathrm{mg} / \mathrm{kg}$.

\section{Acetic acid-induced writhing test}

Table-3 revealed the analgesic effects of NNF and aspirin using acetic acid-induced writhing test. Number of writhes was highly significantly reduced at 50,100 and $200 \mathrm{mg} / \mathrm{kg}$ doses of NNF extract but maximum effects were observed at extract dose of $200 \mathrm{mg} / \mathrm{kg}$ i.e. $11.42 \pm 0.57$ as compared to control $22.14 \pm 0.46$, indicating 48.41 $\%$ inhibition of writhes. On the other hand aspirin also decreased highly significantly number of writhes at doses 50, 100 and 200 $\mathrm{mg} / \mathrm{kg}$, representing $65.8,72.89$ and $79.35 \%$ inhibition of writhes as compared to number of writhes in control animals. 
Table 1: Analgesic effect of NNF and aspirin in tail-flick test demonstrating tail-flick latency difference in mice

\begin{tabular}{|c|c|c|c|c|c|c|c|}
\hline \multirow{2}{*}{$\begin{array}{l}\text { Groups/ } \\
\text { doses }\end{array}$} & \multicolumn{7}{|c|}{ Analgesia TFLD or average increase in latency after drug administration \pm SEM } \\
\hline & Pre-drug & $30 \mathrm{~min}$ & $60 \mathrm{~min}$ & $90 \mathrm{~min}$ & $120 \mathrm{~min}$ & $150 \mathrm{~min}$ & $180 \mathrm{~min}$ \\
\hline Control & $0.9 \pm$ & $0.9 \pm$ & $0.9 \pm$ & $0.9 \pm$ & $0.9 \pm$ & $0.9 \pm$ & $0.9 \pm$ \\
\hline $10 \mathrm{ml} / \mathrm{kg}$ & 0.01 & 0.05 & 0.01 & 0.02 & 0.03 & 0.02 & 0.02 \\
\hline \multirow[t]{2}{*}{$\mathrm{NNF} 50 \mathrm{mg} / \mathrm{kg}$} & $1.0 \pm$ & $1.6 \pm$ & $1.6 \pm$ & $1.6 \pm$ & $1.3 \pm$ & $1.3 \pm$ & $1.2 \pm$ \\
\hline & 0.01 & $0.10^{* *}$ & $0.12^{* *}$ & $0.12^{* *}$ & $0.14^{*}$ & $0.11^{*}$ & 0.14 \\
\hline \multirow[t]{2}{*}{ NNF $100 \mathrm{mg} / \mathrm{kg}$} & $1.0 \pm$ & $2.7 \pm$ & $3.5 \pm$ & $3.9 \pm$ & $3.2 \pm$ & $2.4 \pm$ & $2.3 \pm$ \\
\hline & 0.02 & $0.33^{* *}$ & $0.24^{* *}$ & $0.40^{* *}$ & $0.21^{* *}$ & $0.15^{* *}$ & $0.17^{* *}$ \\
\hline \multirow[t]{2}{*}{ NNF $200 \mathrm{mg} / \mathrm{kg}$} & $0.9 \pm$ & $2.8 \pm$ & $3.9 \pm$ & $5.1 \pm$ & $4.5 \pm$ & $3.3 \pm$ & $3.1 \pm$ \\
\hline & 0.04 & $0.26^{* *}$ & $0.15^{* *}$ & $0.26^{* *}$ & $0.46^{* *}$ & $0.30^{* *}$ & $0.12^{* *}$ \\
\hline Aspirin & $1.0 \pm$ & $3.2 \pm$ & $4.3 \pm$ & $4.8 \pm$ & $4.2 \pm$ & $3.2 \pm$ & $2.8 \pm$ \\
\hline $50 \mathrm{mg} / \mathrm{kg}$ & 0.03 & $0.13^{* *}$ & $0.60 * *$ & $0.62^{* *}$ & $0.42^{* *}$ & $0.23^{* *}$ & $0.64 * *$ \\
\hline \multirow[t]{2}{*}{ Aspirin $100 \mathrm{mg} / \mathrm{kg}$} & $1.0 \pm$ & $3.7 \pm$ & $5.7 \pm$ & $5.7 \pm$ & $4.8 \pm$ & $3.6 \pm$ & $3.0 \pm$ \\
\hline & 0.02 & $0.06^{* *}$ & $0.51^{* *}$ & $0.37^{* *}$ & $0.15^{* *}$ & $0.29^{* *}$ & $0.19^{* *}$ \\
\hline Aspirin & $1.104 \pm$ & $2.695 \pm$ & $4.75 \pm$ & $6.411 \pm$ & $4.249 \pm$ & $4.199 \pm$ & $4.064 \pm$ \\
\hline $200 \mathrm{mg} / \mathrm{kg}$ & 0.14 & $0.21^{* *}$ & $0.45^{* *}$ & $0.49 * *$ & $0.23^{* *}$ & $0.31^{* *}$ & $0.24^{* *}$ \\
\hline
\end{tabular}

$n=7$, The expressions were calculated by taking mean \pm standard error to the mean, *p-value less than 0.05 was counted as significant in comparison to control, ${ }^{* *}$ p value less than 0.005 was counted as extremely significant in comparison to control

Table 2: Analgesic effect of NNF and aspirin in tail-flick test demonstrating \% tail elongation time in mice

\begin{tabular}{ll}
\hline Groups/Doses & \% tail elongation at $\mathbf{9 0}$ min \\
\hline Control $10 \mathrm{ml} / \mathrm{kg}$ & - \\
NNF $50 \mathrm{mg} / \mathrm{kg}$ & 42 \\
NNF $100 \mathrm{mg} / \mathrm{kg}$ & 76 \\
NNF $200 \mathrm{mg} / \mathrm{kg}$ & 82 \\
Aspirin $50 \mathrm{mg} / \mathrm{kg}$ & 81 \\
Aspirin $100 \mathrm{mg} / \mathrm{kg}$ & 84 \\
Aspirin $200 \mathrm{mg} / \mathrm{kg}$ & 95 \\
\hline
\end{tabular}

Table 3: Analgesic effect of NNF and aspirin in acetic acid-induced, writhing test in mice

\begin{tabular}{llll}
\hline Drugs & Dose & Number of writhes & \% Inhibition \\
\hline Control & $10 \mathrm{ml} / \mathrm{kg}$ & $22.1 \pm 0.46$ & - \\
$\mathrm{NNF}$ & $50 \mathrm{mg} / \mathrm{kg}$ & $16.3 \pm 0.29^{* *}$ & 26.46 \\
$\mathrm{NNF}$ & $100 \mathrm{mg} / \mathrm{kg}$ & $12.5 \pm 0.20^{* *}$ & 43.22 \\
$\mathrm{NNF}$ & $200 \mathrm{mg} / \mathrm{kg}$ & $11.4 \pm 0.57^{* *}$ & 48.41 \\
Aspirin & $50 \mathrm{mg} / \mathrm{kg}$ & $7.5 \pm 0.20^{* *}$ & 65.8 \\
Aspirin & $100 \mathrm{mg} / \mathrm{kg}$ & $6.0 \pm 0.31^{* *}$ & 72.89 \\
Aspirin & $200 \mathrm{mg} / \mathrm{kg}$ & $4.5 \pm 0.20^{* *}$ & 79.35 \\
\hline
\end{tabular}

$n=7$, The expressions were calculated by taking mean \pm standard error to the mean, * p value less than 0.05 was counted as significant in comparison to control, ${ }^{* *}$ p value less than 0.005 was counted as extremely significant as compared to control

\section{DISCUSSION}

In current study analgesic effects of NNF was evaluated utilizing couple of animal models against aspirin as it is a remarkably wellrecognized analgesic agent. Aspirin produces analgesia via nonselective and irreversible inhibition of cyclooxygenase enzyme (COX) which in turn decreases the synthesis of prostaglandins and reduces prostaglandins induced pain, inflammation and fever [28]. Despite the fact that aspirin does have a central component of action but it primarily produces analgesia via its peripheral action [29].

Tail flick test is efficient in evaluating the potency and efficacy of centrally acting analgesics [30]. In tail-flick test NNF exhibited highly noteworthy analgesic action at all doses; nevertheless the effects were especially intense at doses 100 and $200 \mathrm{mg} / \mathrm{kg}$. The peek antinociceptive effect at all doses of fruit extract was observed at $90 \mathrm{~min}$ after which gradual decline in analgesic activity was recorded which was highly similar in pattern with aspirin. The percentage of tail elongation time was highest at a dose of $200 \mathrm{mg} / \mathrm{kg}$ i.e. $82 \%$ at 90 $\min$. The higher the \% elongation time of the group the greater is the group's central analgesic effect [25]. Hence it can be stated that NNF at dose of $200 \mathrm{mg} / \mathrm{kg}$ revealed strong central analgesic activity at 90 min after its administration.

Acetic acid-induced writhing test is a widely used method for the evaluation of visceral pain model in rodents [31]. It is also known as the abdominal constrictor response and is very perceptive in detecting anti-nociceptive activities of agents at dose levels that may appear inactive in other procedures [32,33].

The present study depicted and confirmed analgesic effects of NNF using acetic acid-induced writhing test. The number of writhes was highly significantly reduced at doses of 50,100 and $200 \mathrm{mg} / \mathrm{kg}$ of NNF but maximum effects were observed at extract dose of 200 $\mathrm{mg} / \mathrm{kg}$ in comparison to control, indicating $48.41 \%$ inhibition of writhes.

Local presence of peritoneal receptors is assumed to be partially involved in abdominal constrictor response [34]. This method is linked with enhanced levels of $\mathrm{PGE}_{2}$ and $\mathrm{PGF}_{2 \alpha}$ along with lipoxygenase products in abdominal fluid $[35,36]$. Acetic acid intraperitoneal administration also causes the release of inflammatory mediators i.e. bradykinin and histamine which excites nerve fibers responsible for transmitting signals to the advanced centers of the brain and spinal cord which amalgamate and modulate nociception [37].

Since flavonoids, saponins and tannins are important secondary metabolites of NNF and have exhibited inhibitory effects on arachidonic acid metabolism and prostaglandin synthesis [38-40]. Therefore the results of the tail flick test and acetic acid induced writhing test strongly recommend that the mechanism of the analgesic effect of NNF is connected with the blockade of 
arachidonic acid metabolism and inhibition of prostaglandin synthesis.

\section{CONCLUSION}

NNF has demonstrated remarkable analgesic activity in both experiments i.e. tail-flick test and acetic acid-induced writhing test, which was comparable with aspirin and that is perhaps both segments of the NNF i.e. seeds and pods are rich in flavonoids, saponins and tannins. Hence NNF seems to have a great potential for therapeutic applications especially in the treatment of disorders associated with pain and strongly supports more experimental trials in this field.

\section{ACKNOWLEDGMENT}

The authors are thankful to the Chairman Pharmacognosy Department, Karachi University for identification and authentication of NNF and also appreciate the support of Director, International Center for Chemical and Biological Sciences (ICCBS) for permitting us to use their facilities to complete this piece of work.

\section{AUTHORS CONTRIBUTIONS}

All authors have contributed equally in this piece of work

\section{CONFLICT OF INTERESTS}

The authors declared no conflict of interest

\section{REFERENCES}

1. Yesilada E, Ustun O, Sezik E, Takaishi Y, Ono Y, Honda G. Inhibitory effect of turkish folk remedies on inflammatory cytokines: interleukins-1-alpha, interleukins-1-beta and tumor necrosis factor-alpha. J Ethnopharmacol 1997;58:5973.

2. Corley DA, Kerlikowske K, Verma R, Buffler P. Protective association of aspirin/NSAIDS and esophageal cancer: a systemic review and meta-analysis. Gastroenterology 2003; 124:47-56.

3. Leonardo DCL, Franco A, Gustavo ATL, Luciano MA, Lius FMES, Gabriele PDS, et al. Toxicological assessments of aqueous extract of Eugenia jambolanastem bark. Toxicol Lett 2000;116:189-98.

4. Singh M, Kumar V, Singh I, Gauttam V, Kalia AN. Antiinflammatory activity of aqueous extract of Mirabilis jalapa linn leaves. Pharmacognosy 2010;2:64-7.

5. Agbaje EO, Adeneye AA, Daramola AO. Biochemical and toxicological studies of aqueous extract of Syzigium aromaticum L. Merr. and perry myrtaceae in rodents. Afr J Trad CAM 2009;6:3, 241-54.

6. Mukherjee PK, Mukherjee D, Maji AK, Rai S, Mukherjee PK, Saha $\mathrm{K}$, et al. The sacred lotus (Nelumbo nucifera) phytochemical and therapeutic profile. J Pharm Pharmacol 2009;61:407-22.

7. Sridhar KR, Bhat R. Lotus: a potential nutraceutical source. J Agric Technol 2007;3:143-55.

8. Carlo FM, Masami Y, Yoshiaki K, Ganesh KA, Randeep Rakwal. Lotus-a source of food and medicine: current status and future perspectives in context of the seed proteomics. Int J Life Sci Technol 2013;7:1-5.

9. Indrayan AK, Sharma S, Durgapal D, Kumar N, Kumar M. Determination of nutritive value and analysis of mineral elements for some medicinally valued plants from Uttaranchal. Curr Sci 2005;89:1252-5.

10. Pal I, Dey P. A review on lotus (Nelumbo nucifera) seed. Int J Sci Res 2015;4:1659-66.

11. Rajput MA, Khan RA. Phytochemical screening, acute toxicity, anxiolytic and antidepressant activities of Nelumbo nucifera fruit. Metab Brain Dis 2017;32:743-49.

12. Chopra RN, Chopra IC, Nayar SL. Glossary of Indian medicinal plants. New Delhi: Council of Scientific and Industrial Research; 1996. p. 174.

13. Varshney CK, Rzoska J. Aquatic weeds in South East Asia. $1^{\text {st }}$ ed. New Delhi: Springer; 1976. p. 39.

14. Rajput MA, Khan RA, Assad T. Anti-epileptic activity of Nelumbo nucifera fruit. Metab Brain Dis 2017;32:1883-7.
15. National Advisory Committee for Laboratory Animal Research. Guidelines on the care and use of animals for scientific purposes; 2004. p. 24.

16. National Institute of Health Guidelines for Care and Use of Laboratory Animals in Biomedical Research. Guide for the care and use of laboratory animals. Prepublication draft. $8^{\text {the }}$. The National Academies Press: Washington DC; 2010. p. 6, 47.

17. Hossain MS, Ahmed M, Islam A. Hypolipidemic and hepatoprotective effects of different fractions of ethanolic extract of immature leaves of Mangifera indica Linn in alloxaninduced diabetic rats. J Pharm Sci Res 2010;1:132-8.

18. Assad T, Khan RA, Rajput MA. Effect of Trigonella foenumgraecum linn. seeds methanol extract on learning and memory. Metab Brain Dis 2018;33:1275-80.

19. Madhu A, Keerthi PHV, Singh J, Shivalinge GKP. To evaluate the antiepileptic activity of aqueous root extract of Hemidesmus indicus in rats. Arch Pharm Sci 2009;1:1, 43-7.

20. Khan RA, Rajput MA, Assad T. Effect of Nelumbo nucifera fruit on scopolamine-induced memory deficits and on motor coordination. Metab Brain Dis 2018;34:1, 87-92.

21. Ahmed S, Naved A, Khan RA, Siddiqui S. Analgesic activities of methanol extract of Terminalia chebula fruit. Pharmacol Pharm 2015;6:547-53.

22. Bukhari IA, Khan RA, Gilani AH, Ahmed, Saeed SA. Analgesic, anti-inflammatory and anti-platelet activities of the methanolic extract of Acacia modesta leaves. Inflammopharmacology 2010;18:187-96.

23. Luiz CDS, Mirtes C, Sigrid LJ, Mizuekirizawa M, Cecilia G, Jrotin GJ. Studies on medicinal plants of sri lanka, toxicity of some traditional medicinal herbs. J Ethnopharmacol 1998;24:205-11.

24. Dashti Rahmatabadi MH, Hejazian SH, Morshedi A, Rafati A. The analgesic effect of carum copticum extract and morphine on phasic pain in mice. J Ethnopharmacol 2007;109:226-8.

25. Islam R, Sikder MAA, Khan RA, Ahmed M, Rashid MA. Membrane stabilizing, thrombolytic, analgesic, anti-diarrheal and CNS activities of Polyalthia longifolia. South Asian J Exp Biol 2014;4:104-9.

26. Koster R, Anderson M, De Beer EJ. Acetic acid for analgesic screening. Fed Proc 1959;18:412-7.

27. Walpole RE. Introduction of statistics. Third Edition. Macmillan Publishing Company, Inc., New York; 1982. p. 247-304.

28. Besson JM, Chaouch A. Peripheral and spinal mechanisms of nociception. Physiol Rev 1987;167:67-186.

29. Barsante MM, Roffe E, Yokoro CM, Tafuri WL, Souza DG, Pinho $\mathrm{V}$, et al. Anti-inflammatory and analgesic effects of atorvastatin in a rat model of adjuvant-induced arthritis. Eur J Pharmacol 2005;516:282-9.

30. Brownlee G. Effect of deoxycortone and ascorbic acid on formaldehyde induced arthritis in normal and adrenalectomized rats. Lancet 1950;28:157-59.

31. Moloney RD, O'Mahony SM, Dinan TG, Cryan JF. Stressinduced visceral pain: toward animal models of irritable bowel syndrome and associated comorbidities. Front Mol Psychiatry 2015;6:15.

32. Bentley GA, Newton SH, Starr J. Evidence for an action of morphine and enkephallins on sensory nerves endings in the mouse peritoneum. Br J Pharmacol 1981;73:325-32.

33. Bentley GA, Newton SH, Starr J. Studies on the anti-nociceptive action of $\alpha$-agonist drugs and their interaction with opioid mechanisms. Br J Pharmacol 1983;79:125-34.

34. Derardt R, Jougney S, Delvalcee F, Falhout M. Release of prostaglandin's e and $\mathrm{f}$ in an algogenic reaction and its Inhibition. Eur J Pharmacol 1980;51:17-24.

35. Levini JD, Lau W, Kwait G, Goetzl EJ. Leukotriene $\beta 4$ products hyperalgesia that is dependent on the polymorphonuclear leukocytes. Sciences 1984;225:743-5.

36. Dhara AK, Suba V, Sen T, Pal S, Nag CAA. Preliminary studies on the anti-inflammatory and analgesic activity of the methanolic fraction of the root extract of Tragia involucrate. J Ethnopharmacol 2000;72:265-8.

37. Evan FE, Andrew K. Acute pain following musculoskeletal injuries and orthopedic surgery. J Bone Joint Surgery 2004;86:1316-27. 
38. Ahmadiani A, Fereidoni M, Semnanian S, Kamalinejad M, Saremi S. Anti-nociceptive and anti-inflammatory effects of Sambucusebulus rhizome extract in rats. J Ethnopharmacol 1998;61:229-35.

39. Ahmadiani A, Hosseiny J, Semnanian S, Javan M, Saeedi F, Kamalinejad M, et al. Anti-nociceptive and anti-inflammatory effects of Eleagnusangusti folia fruit extract. J Ethnopharmacol 2000;72:287-92.

40. Chindo BA, Joseph AA, Edmond I, Ahmadu AA, Tarfa FD, Karniyus SG. Saponins are involved in the analgesic and antiinflammatory properties of Ficus platyphylla stem bark. Int J Biol Chem Sci 2010;4:415-23. 